\title{
DEVELOPMENT OF EQUIPMENT FOR LOADING POST-HARVEST PRODUCTS ON HIGH MEANS
}

\author{
El Awady, M. N. ${ }^{(*)}$ El Sahhar, E. S. ${ }^{(* *)}$ Al-Shaymaa;M. Abdel-Zaher ${ }^{(* * *)}$
}

\begin{abstract}
This research represents some designable and operational factors for development of a product handling machine. A throwing machine was developed to suit the loading of tubers, such as: potatoes - sugar beettable beet. The important designing and operating factors were studied, including: rotational speed - angle of throwing from the machine to fall a trailer - and initial throwing height. A model was made to simulate the machine by scale 1:2 with some changes in rotational speed, vanes angle, initial height, and throwing angle to suit tubers. The experiment was run on potato tubers. This machine is for use in loading tubers on trailers after harvesting for sorting and storage. Experiment included: range of rotational speeds from 300 to $800 \mathrm{rpm}$, two vanes rotor driven by motor shaft, three angles of throwing (55, 65, and 75 degrees), and changes in height of throwing and distance to the trailer.

Results revealed the following

* The most suitable angle of machine to throwing is 75 degree with horizontal direction

* The most suitable rotational speed range with less damage in tubers is 500 to $600 \mathrm{rpm}$

* Radial vanes was given best results

* The maximum tubers throwing height was 3:4 m

* The suitable horizontal distance to trailer with the highest throwing conditions of experiment was $3: 5 \mathrm{~m}$.

* The maximum efficiency of loading by designed machine model was $77 \%$.
\end{abstract}

(*) Prof. Emerit; Ag. Eng.,

(**) Prof. and Head of the Ag. Eng. Dep.

(***)T. A.; Eng.; all in Col. Ag.; Ain Shams U. 


\section{INTRODUCTION}

Duber crops are one of the most important crops in Egypt, with an area of 13752 ha and productivity of $25939 \mathrm{~kg} / \mathrm{ha}$.Sugar beet

1 area is 10822 ha with productivity of $47427 \mathrm{~kg} / \mathrm{ha}$ in the year 2008 (according to Arab Agricultural Statistics Yearbook, 2009). Harvesting is carried out by using chisel ploughs to dig tubers up soil surface and then they are collected to transport to grading and package places. Handling operation of tubers is mostly by hand but machines have small role in it (Kepner et al., 1982).

Trevor and Ron (1991) reported that harvesting and handling and packaging of potatoes must be carried out very carefully in order to prevent mechanical damage to the tubers which have high sensitivity, thin skin and a high degree of fullness in the cells. They added that the brown spots are produced as a result of bruising and bad handling and appear in the form of discoloration beneath the surface of tubers.

The most important equipment used in transportation and loading operations are:loaders, loading cranes, agricultural trailers (capacities 2:8 ton), lifting forks attached to tractor, conveyor belts (used for small distances), and machines of fodder handling. (Kepner et al. 1982)

Soliman et al. (1999) concluded that the shape of Alpha potato is oval while sponta potato variety is long. According to ASAE, standards, 1998 large potatoes $>89 \mathrm{~mm}$ diameter with a low specific gravity of 1.050 $\mathrm{g} / \mathrm{cm}^{3}$ reach the smaller bulk density value. Small potatoes $<51 \mathrm{~mm}$ diameter have a high specific gravity of $1.10 \mathrm{~g} / \mathrm{cm}^{3}$.

Gamea et al. (2009) stated that the average measured surface areas were 134.45 and $168.8 \mathrm{~cm}^{3}$ for fresh potato tubers: Dimont and Santana varieties, respectively. They stated that the average particle and bulk densities of fresh potato tubers were $0.968: 1.26 \mathrm{~g} / \mathrm{cm}^{3}$ and 0.924 to $1.221 \mathrm{~g} / \mathrm{cm}^{3}$ for Dimont and Santana varieties, respectively. The mean values of repose angle of tubers were $31^{\circ} 33^{\circ}$ and $34^{\circ} 50^{\circ}$ for Dimont and Santana varieties respectively.

The aim of this study is to investigate the possibility of a small machine handling to load tubers to overcome hand-labor shortage and reduce cost and losses. 
The machine of this research is for use in loading tubers on trailers after harvesting for sorting and storage, and determination of the suitable designing factors to achieve it.

\section{MATERIALS AND METHODS}

\section{1- Description of the loading machine}

An experimental prototype of loading machine was designed and constructed for loading the potato tubers in the workshop of the Agri. Eng. Dept., Fac. of Agric., Ain Shams Univ. The construction and dimensions are shown in Fig.(1). The main components of the loading machine are:

1) Thrower unit: Two vanes were fixed axially on flange which rotates through a circular casing $50-\mathrm{cm}$ diameter and $20-\mathrm{cm}$ width. The impeller shaft is $30-\mathrm{cm}$ long and $20-\mathrm{cm}$ diameter rotates through two ball bearings bolted to the frame. The thrower unit has a feeding part $30-\mathrm{cm}$ diameter beside the casing and outlet at the upper side, which had a cross section of $20 * 20-\mathrm{cm}$.

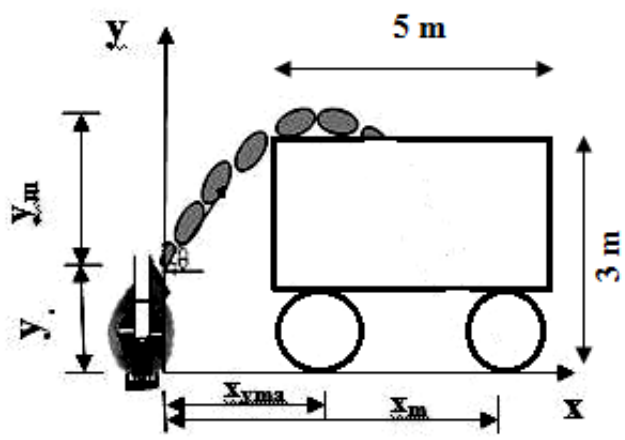

Fig. (1): The loading machine with truck.

where : $X_{\max }$ is the range at the maximum high, $X_{y \max }$ is the maximum range of tubers, $y_{\circ}$ is the constant high of machine $(500 \mathrm{~mm})$, and $y_{\max }$ is the maximum vertical high of tuber.

mechanical function such as : identify range of working pressure, injection. 
2) Frame: The frame was made of steel angles $2.5 * 2.5-\mathrm{cm}$ to fix the electric motor, thrower unit and motion transmission system.

3) Motion transmission: transmitted from electric motor $(0.4 \mathrm{~kW}$ at $1800 \mathrm{rpm}$ ) by a V.belt and stepped pulleys for 6 speed changes. The diameters of the motor pulley are 5 and $7-\mathrm{cm}$, while those of the vane pulley are 15,17 and 20-cm for up step ratios of 2.14:1 to 4:1.

4) Feeding guide: A smooth half tube of plastic $7.5-\mathrm{cm}$ diameter and $120-\mathrm{cm}$ length is used to guide the potato tubers to the feeding slot, and prevent scattering of the tubers. In addition, it gives safety to worker if potato tubers happen to rebound during feeding operation. , As shown in Fig.(2).

It was stand of steel to carry the guide which made of two long steel angles with 100 and 30-cm long.

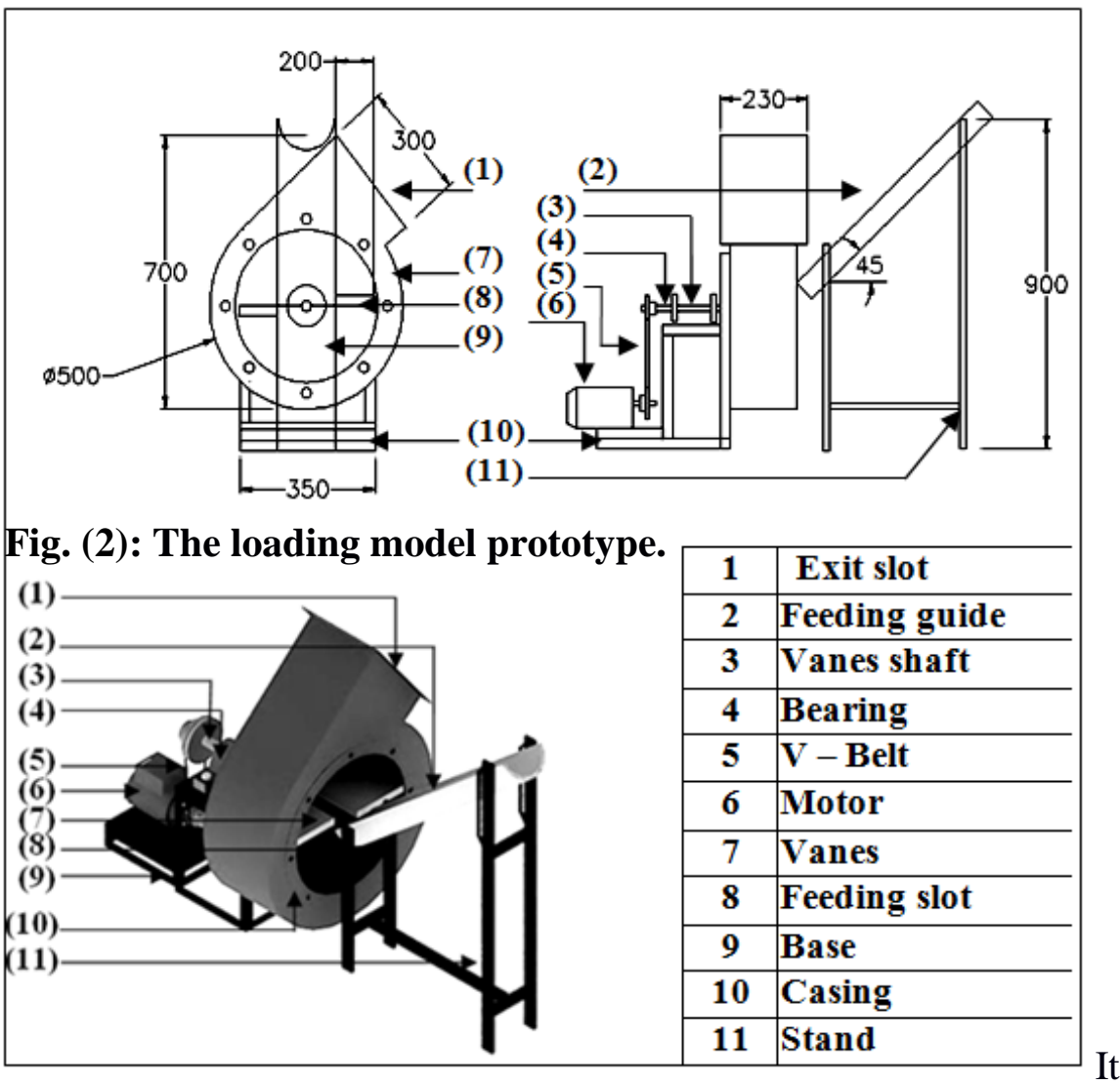




\section{2- Methods and calculations}

1) Productivity and efficiency:

\section{A) Hand-labor productivity:}

To evaluate theoretical and actual productivities (the following measurements were taken):

* Total time $=0.1 \mathrm{~h}$

* Total mass of potato tubers in the experiment $=24 \mathrm{~kg}$

* Angle of handling $=75^{\circ}$ approximately, as shown in Fig. (3)

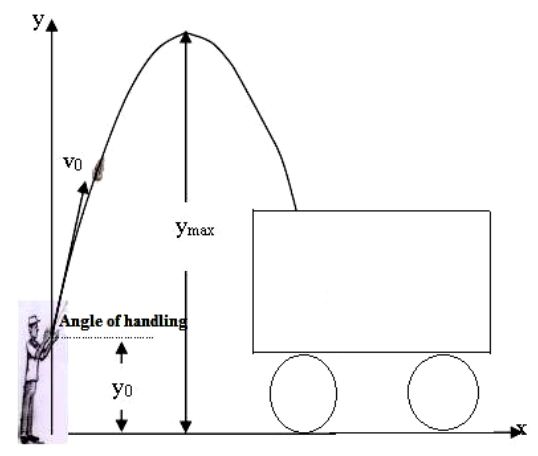

Fig. (3): Angle of manual handling.

We can calculate productivity by the following:

Theoretical Pro. $=$ Theo. mass $/$ total time

Eq. (1)

Where:

* Theo. mass is the total weight which handling measured by balance "ton"

* Total time measured by stop watch "h"

Actual Pro. = Act. mass / total time

Eq. (2)

Where:

* Act. mass is the filling to in the trailer measured by balance "ton

* Total time measured by stop watch "h"

B) Machine productivity:

Productivity was measured to evaluate theoretical and actual productivities by machine handling under the following conditions:

* Total time $=0.23 \mathrm{~h}$

* Total mass of potato tubers $=55 \mathrm{~kg}$

* Angle of outlet of machine $=75^{\circ}$ 
Productivity can calculate it by this equation:

\section{Theoretical Pro. $=$ Theo. mass $/$ total time}

Where:

* Theo. mass is the total weight which handling measured by balance "ton"

* Total time measured by stop watch "h"

Actual Pro. = Act. mass / total time

Where:

* Act. mass is the what loaded to in the trailer measured by balance "ton"

* Total time measured by stop watch "h"

C) Handling efficiency:

Handling efficiency $=$ Actual productivity $/$ Theoretical productivity Eq. (3)

Where:

* Actual productivity "ton/h"

* Theoretical productivity "ton/h"

2) Exit angle " $\theta$ ":

" $\theta$ " was measured before experiment in the range $45^{\circ}: 90^{\circ}$ to choose suitable exit angle using protractor as shown in fig. (4).

3) Vanes Angle:

There are two radial vanes as shown in fig. (5).

4) Rotational speeds " $n$ ":

"n" was In the range between 300 to $800 \mathrm{rpm}$ to estimate suitable rotational speed for loading with less damage in tubers.

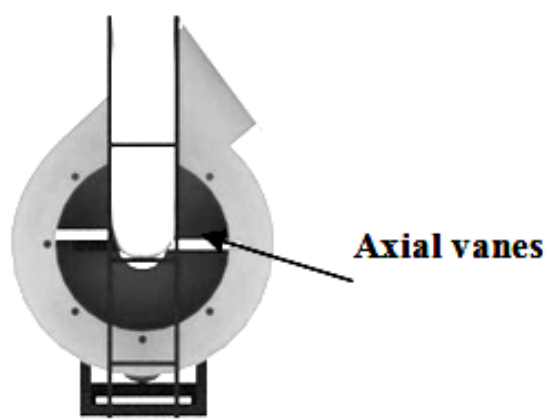

Fig. (4): Exit angle.

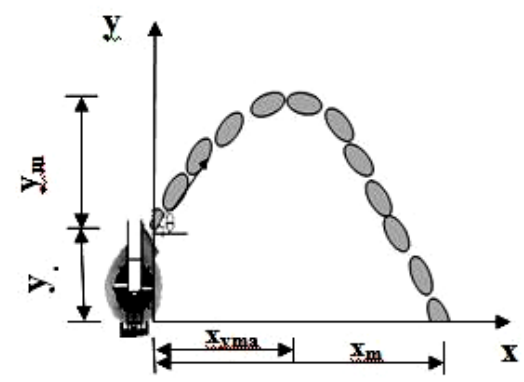

Fig. (5): Axial vanes. 


\section{5) \% Mechanical damage:}

Damage is classified into the following (According to the WSU Bruise Classification System, Hughes, 1980):

1- Crushing.

2- White knot.

3- Internal shatter.

4- External shatter.

5- External cracking.

6) Cost of handling machine:

The cost per unit "L.E./ton" product was determined using the following equation according to (Awady 1978):

$$
\mathrm{C}=\mathrm{p} / \mathrm{h}(1 / \mathrm{e}+\mathrm{i} / 2+\mathrm{t}+\mathrm{r})+(\mathrm{hp} * \mathrm{~s})+\mathrm{w} / 144
$$

Where:

$\mathrm{C}=$ Hourly cost in L.E.

$\mathrm{P}=$ Capital investment in L.E.

$\mathrm{h}=$ Yearly operating hours.

$\mathrm{e}=$ Life expectancy of the machine in years.

$\mathrm{i}=$ Interest rate.

$\mathrm{t}=$ Taxes and overheads ratio.

$r=$ Maintenances and repairs ratio of the total investment.

$\mathrm{hp}=$ Horse power of motor (or $\mathrm{kW})$.

$\mathrm{s}=$ Power unit price;

$\mathrm{w}=$ Labors wage rate per month in L.E.

144: Reasonable estimation of monthly average working hours.

\section{RESULTS AND DISCUSSION}

Obtained results out through several laboratory experiments are presented and discussed through the following points:

1- Physics and mechanical properties of potato tubers:

a- Mass property "m": 
There are frequencies in Dimont tuber masses around the mean mass $150 \mathrm{~g}$.

\section{b- Dimensions "Length, Width, and Thickness":}

There are frequencies of dimensions as follows:

- Length of tubers frequency around $70 \mathrm{~mm}$

- Width of tuber frequency around $70 \mathrm{~mm}$

- Thickness of tubers frequency around $40 \mathrm{~mm}$

c- Volume "V":

There is a mode in Dimont tubers volumes around the mean volume 150 $\mathrm{cm}^{3}$.

\section{d- Density " $\rho$ ":}

There is a mode in Dimont tubers densities around the mean density 1.2 $\mathrm{g} / \mathrm{cm}^{3}$.

\section{e- Mechanical damage classes:}

Damage is classified into the following (According to the WSU Bruise Classification System, Hughes, 1980):

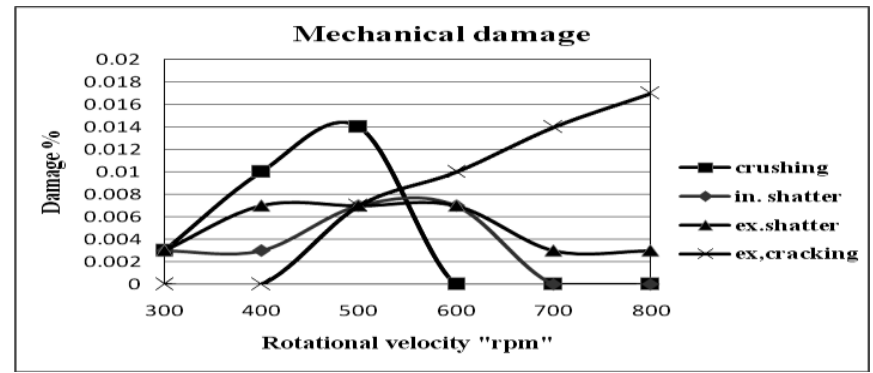

Fig. (6): Mechanical damage classifications.

As shown in fig. (6).

These results show that:

* At the lower rotational speeds tubers had crushing was $0.014 \%$ damage at $500 \mathrm{rpm}$.

* Internal, external shutters in fewer tubers that was $0.006 \%$ damage at $500,600 \mathrm{rpm}$.

* At the high rotational speeds, internal, external shutters decreased and external cracking increased because tubers impact with edges of vanes which gave $0.016 \%$ damage at $800 \mathrm{rpm}$.

\section{2- Productivity and efficiency:}

As shown in fig. (7): 


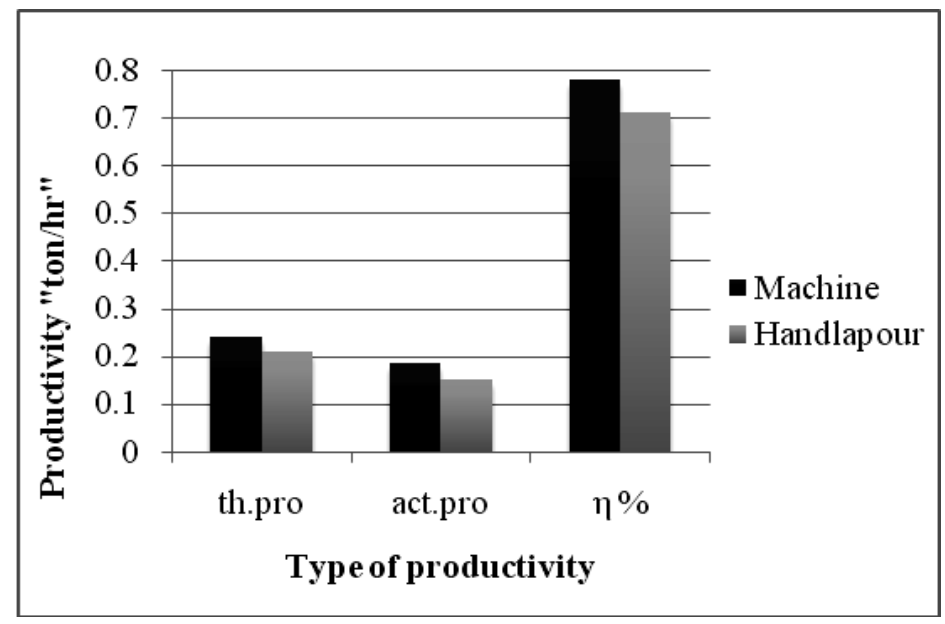

Fig. (7): Machine and manual handling productivity.

There were showing that:

* Machine can handle $0.24 \mathrm{ton} / \mathrm{h}$ as theoretical productivity, where manual handling can make 0.21 ton/h.

* Machine can handle $0.187 \mathrm{ton} / \mathrm{h}$ as actual productivity, where manual handling can make 0.15 ton/h.

* Machine efficiency was greater than manual handling, where it was $78 \%$ by machine compared with $71 \%$ by manual handling.

\section{3- Outlet angle ( $\theta)$ :}

The optimum outlet angle of tuber studied was in the range between $45^{\circ}$ to $90^{\circ}$ according to the trajectory equations: As shown in fig. (8):

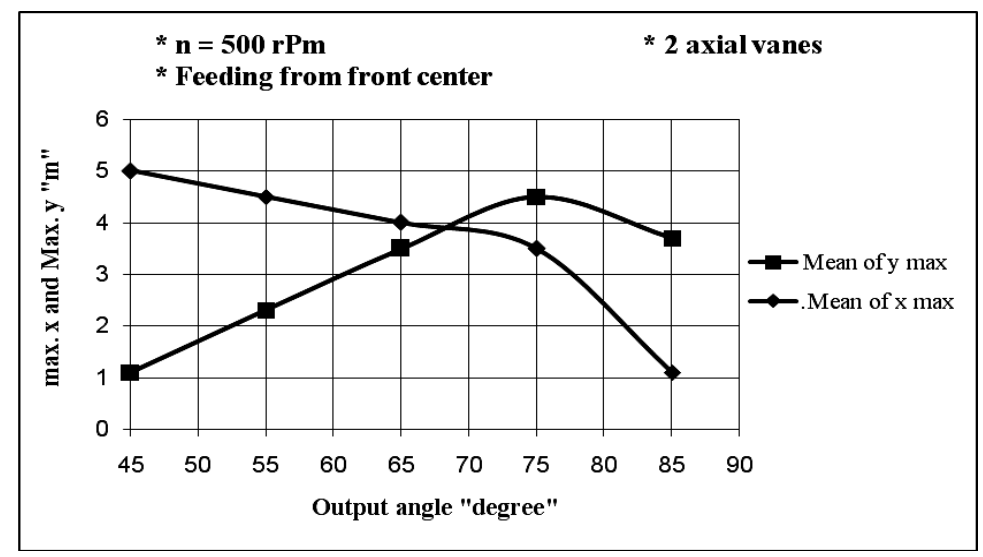

Fig. (8): Angle of outlet. 


\section{4- Cost analysis:}

The cost of loading process per trailer or lorry is estimated by 2 systems:

(1) The designed machine operated by a $0.4 \mathrm{~kW}$ electric motor.

(2) Manual loading for comparison.

(3) The operation cost was estimated according to Awady (1978) as stated in the "Materials and Methods" section, with the relevant nomenclature.

$$
\mathrm{C}=\mathrm{p} / \mathrm{h}(1 / \mathrm{e}+\mathrm{i} / 2+\mathrm{t}+\mathrm{r})+(\mathrm{hp} * \mathrm{~s})+\mathrm{w} / 144
$$

So the cost will be:

\section{Item}

$\mathrm{p}$
$\mathrm{h}$
$\mathrm{e}$
$\mathrm{i}$
$\mathrm{t}$
$\mathrm{r}$

hp

$\mathrm{s}$

W
Description

Capital investment for handling machine

Yearly operating hours for handling machine

Life expectancy for equipment in general

Interest rate

Taxes and overheads ratio

Maintenances and repairs ratio of the total

investment

Power of electric motor

Power unit price

Labor wage rate per month
Value

2000 L.E.

$750 \mathrm{~h}$

10 years

$12 \%$

0.05

0.1

$0.4 \mathrm{~kW}$

0.2L.E. /kW. h

500 L.E.

Cost per hour "C" $=2000 / 720(1 / 10+0.12 / 2+0.05+0.1)+(0.4 * 0.2)$

$+500 / 144=3.535$ L.E./h.

* Trailer or lorry capacity assumes $=\mathbf{1 6}$ ton.

\section{(1) For the designable machine:}

* Handling machine productivity was 0.187 ton/h

* The cost of handling machine per ton $=$ cost per hour / productivity $=3.535 / 0.187=18.9$ L.E. $/$ ton. 
(2) For the manual handling:

* Assume that the handling operation needs one labor, with wage 500 L.E./month.

* Hence, $\quad \mathrm{C}=\mathbf{5 0 0} / \mathbf{1 4 4}=\mathbf{3 . 4 7 2}$ L.E./h.

* Productivity for labor was $=\mathbf{0 . 1 5}$ ton $/ \mathbf{h}$,

* Hence, the cost of manual handling per ton $=\mathbf{3 . 4 7 2} / \mathbf{0 . 1 5}$

\section{$=23.148$ L.E./ton.}

From these results:

The handling process costs by using the designed machine were 18.9 L.E./ton. Manual handling one ton needs about 23.148 L.E. it could be said that, using the designed handling machine reduced the cost of tubers handling to 1: 1.22 as compared with manual method.

\section{SUMMARY AND CONCLUSION}

The main results in this study can be summarized in the following points:

\section{1- Physical and mechanical properties of potato tubers:}

- Mass mean of Dimont tubers was $150 \mathrm{~g}$ approximately.

- Length of tubers was around $70 \mathrm{~mm}$

- $\quad$ Width of tuber was around $70 \mathrm{~mm}$

- Thickness of tubers was around $40 \mathrm{~mm}$

- Volume mean was $150 \mathrm{~cm}^{3}$ approximately.

- Density mean was $1.2 \mathrm{~g} / \mathrm{cm}^{3}$.

- At the lower rotational speeds tubers have crushing's of $0.014 \%$ damage at $500 \mathrm{rpm}$.

- Internal, external shutters resulted in fewer tubers of $0.006 \%$ damage at $500,600 \mathrm{rpm}$. 
- At the high rotational speeds: internal, external shutters decreased and external cracking increased because tubers impact with edges of vanes. That gave $0.016 \%$ damage at $800 \mathrm{rpm}$.

2- Productivity and efficiency:

- Machine can handle $0.24 \mathrm{ton} / \mathrm{h}$ as theoretical productivity, where manual handling can make 0.21 ton/h.

- Machine can handle 0.187 ton/h as actual productivity, where manual handling can make 0.15 ton/h.

- Machine efficiency was larger than manual handling, where it was $78 \%$ by machine compared with $71 \%$ by manual handling.

\section{3- Outlet angle ( $\theta)$ :}

Optimum outlet angle was in the range of 65 to 75 degrees.

\section{REFERENCES}

Arab Agricultural Statistics Yearbook, 2009, 29, (3):plant production, tables: 37, 38, 41. Pages: 43, 44, 47.

Awady, M. N. ,1978, Tractor and farm machinery. Txt bk., Col. Ag., Ain Shams U.: 146-167.

Awady, M. N., M. M. Hegazi, A. G. Mohamed, M. A. Ibrahim, and M. F. Mohamed, 2002, Differentiation and Integration, Ag. Eng. Dep. , Col. Ag. , A. Shams U. : p. 3-5/7. (In Arabic).

Gamea, G. R.; Abd El-Maksoud, M. A.; and Abd El-Gawad, A. M. (2009), Physical characteristics and chemical properties of potato tubers under different storage systems. Misr J. Ag. Eng., 26(1): 385408.

Hughes, J. C. (1980). Potatoes I: Factors affecting susceptibility of tubers to damage. Span 23:65-75.Cited by Baritelle, et al (1998a). 
Kepner, D. A., Penner, R., Barger, E.L., Principles of agricultural machinery, 1982, Ch: 20 (harvest), harvesting potatoes, 953-959. Trans. Into Arabic by: Ahmed, A. A., Ali, A. S.,1990.

Soliman, A.F.;E.Y ghoniem and F.M. Abdou (1999). Some physical and mechanical properties of potato concerning the design of diggers and handling operations. The $7^{\text {th }}$ conference of Misr Soc. of Ag. Eng : $290-301$.

Suslow T. V. and R. Voss (1991), Recommendations for maintaining postharvest quality of potato: (Immature early crop) . Postharvest Tec. Res. and Info. C., U. of Cal., Davis .

$$
\text { الملخص العربي }
$$

تطوير معدة لتحميل منتجات ما بعد الحصاد على وسائل مرتفعة

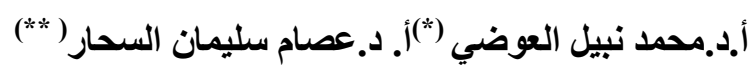

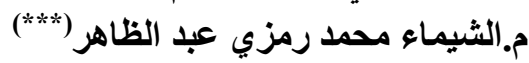

يهدف البحث الى در اسة العو امل التالية : معلات

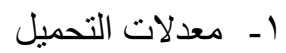

r- الوصول إلى انسب وضع للآلة بالنسبة للثاحنة لضمان سقوط الثمار فيها .

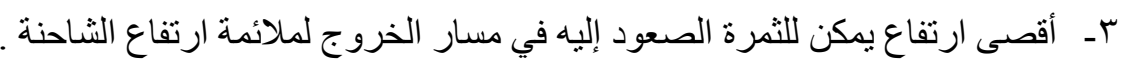

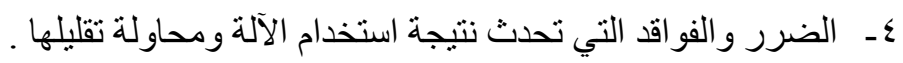
الوصول لأعلى إنتاجية مدكنة من الآلة

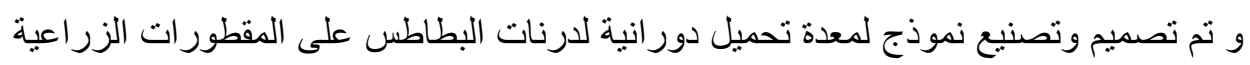

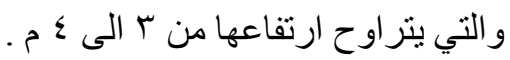

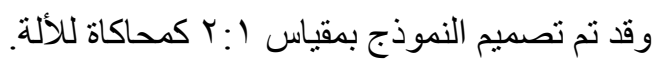

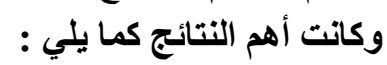

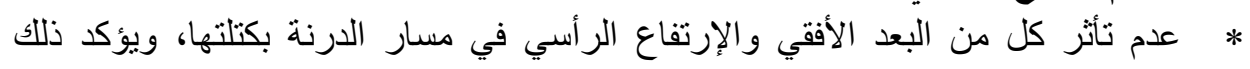

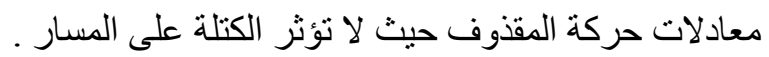

(*) أستاذ الهندسة الزراعية المتفرغ - كلية الزراعة - جامعة عين شمس.

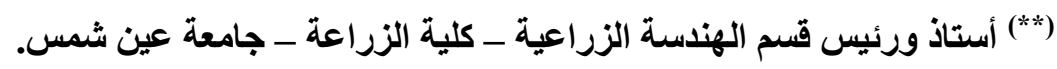

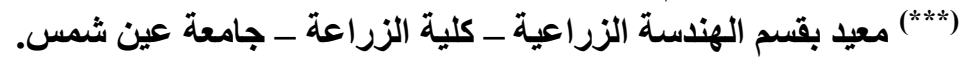




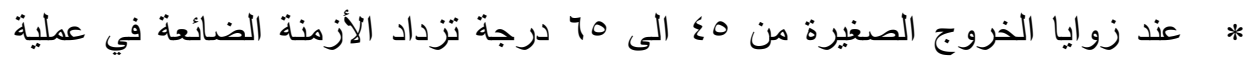

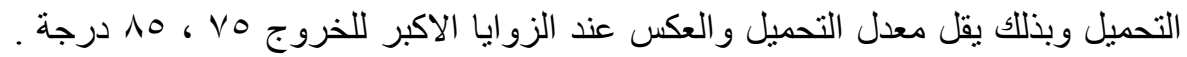

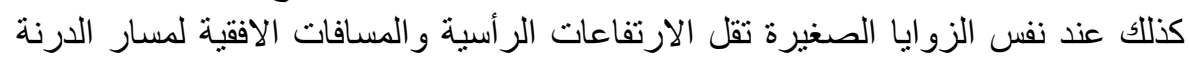
وتزداد بزيادة زاوية الخروج .

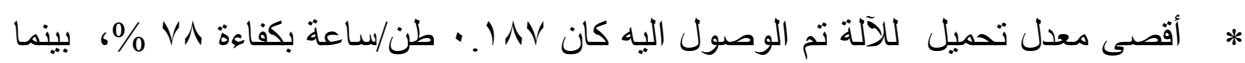

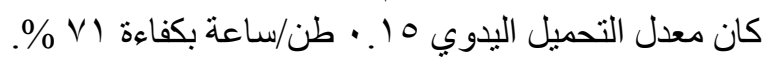
* أقصى بعد أفقي في الظروف المثلى للتجربة وصلت إلبه الدرنات في مسار خروجها من

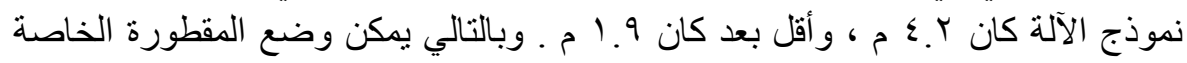

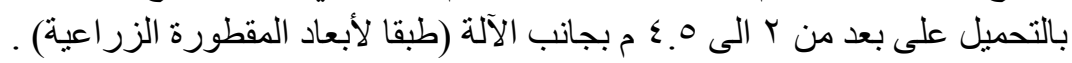
* أقصى إرتفاع رأسي على الظروف المثلى للتجربة تم وصول الدرنات إلبه في مسار

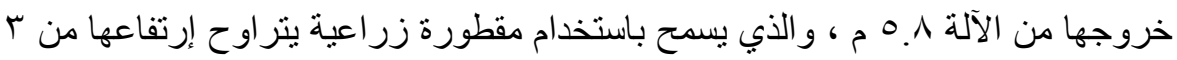

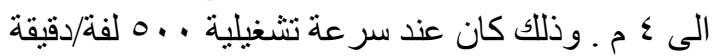

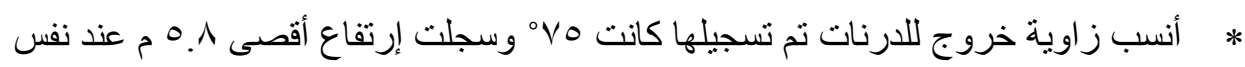
سر عة التشغيل . ماله

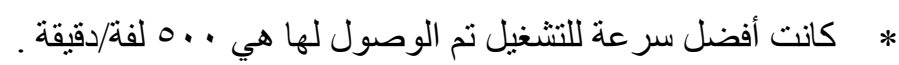

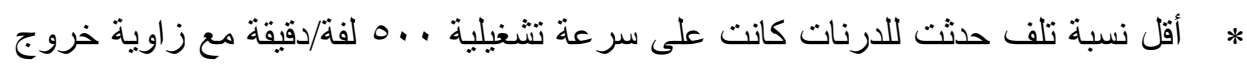
م V درجة .

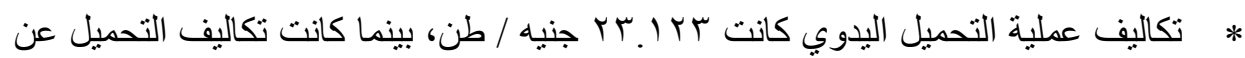
طريق الآلة 9 .11 جنيه / طن الن. 